\title{
Legislative Approaches to the Obesity Epidemic
}

\author{
RACHEL I. WEISS, CHERYL L. HAYNE, and \\ JASON A. SMITH
}

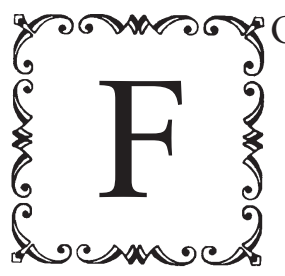

O OD has long been an explicit and implicit subject of both state and federal legislation in the United States. Federal legislation has addressed food safety through the regulation of content and labeling of food products and regulation of the food production environment (I). More indirectly, the Congress has promulgated economic policies that subsidize many aspects of food production, ultimately affecting what foods are available to the consumer. Congress has also mandated and controlled federal programs such as the National School Lunch Program (2). States have enacted laws granting regulatory authority to state agencies that inspect and regulate food consumption. Many states also have statutory consumer protection laws that provide redress for individuals who have been injured by a food product. It is in these areas that legislatures have traditionally acted, and where legal levers for future action reside.

Federal and state legislatures occasionally acknowledge the obesity epidemic, but little is being done to address the root causes of the problem. A long-standing tension, often styled as that between paternalism and individual liberty, pits public health against American individualism. Against a backdrop of government agriculture subsidies and economic protectionism, health is generally regarded as the sole responsibility of the individual consumer. The public and legislatures fail to recognize government and institutional responsibility for the current "toxic" food environment. We provide a brief overview of the role of federal and state legislatures in mitigating the epidemic. Given the breadth of the subject, we have not attempted a comprehensive analysis of legislation. Instead, we focus on three key domains: economic policy, federal programs, and food health and safety. We 
also consider new legislative opportunities in control of judicial procedures and private enforcement.

\section{ECONOMIC LEGISLATION：SUBSIDY POLICY}

Marion Nestle (3) elegantly highlights the striking, if not obvious truth of the U.S. food supply: for the current population of the United States, the market simply provides too much food. This overabundance, created by government economic policies, results in hyper-aggressive competition and marketing to consumers. Food companies jockeying for market dominance cater to the mass market by producing low-cost foods, using fat, sugar and salt to attract consumers. The U.S. Congress supports food industries, particularly agribusiness, through direct subsidies, price fixing, and price supports.

Because of uncertainties inherent in drought, pests, and other causes of crop failure, governments have often helped agriculture expand beyond normal demand, aiding farmers and production. The United States government has formally protected commodities such as beef, poultry, and dairy products since the r930s.

Congress first put food safety policies in place at the turn of the 2oth century. Government agencies using their newly granted police powers, monitored products like milk and butter for contamination and adulteration. At that time, Congress was in an unenviable position. It needed to protect the public from truly harmful food products with the help of rapidly-evolving scientific information while protecting the economy by supporting the politically savvy, economically strong agriculture industry. It chose to protect the public by close regulation of products it deemed harmful, often at the behest of competing industries. Industry influence on government policy in agriculture has been persistent, thus the designation of "harmful" was not always supported by the emerging scientific evidence.

Lawmakers have changed little in the last century; incentives to protect powerful industries can still take precedence over the health of the public. Today, Congress often chooses to forgo legislation that would impose regulatory controls, despite strong evidence that an industry is incapable of regulating itself. For example, the Dairy Production Stabilization Act of 1983 (4) states:

Congress finds that- 
- dairy products are basic foods that are a valuable part of the human diet;

- the production of dairy products plays a significant role in the Nation's economy, the milk from which dairy products are manufactured is produced by thousands of milk producers, and dairy products are consumed by millions of people throughout the United States;

- dairy products must be readily available and marketed efficiently to ensure that the people of the United States receive adequate nourishment; the maintenance and expansion of existing markets for dairy products are vital to the welfare of milk producers and those concerned with marketing, using, and producing dairy products, as well as to the general economy of the Nation;

- and dairy products move in interstate and foreign commerce, and dairy products that do not move in such channels of commerce directly burden or affect interstate commerce of dairy products.

The Act further asserts a public interest for the federal government to finance and promote the U.S. dairy market in order "to strengthen the dairy industry's position in the marketplace and to maintain and expand domestic and foreign markets and uses for fluid milk and dairy products." In the committee report issued upon passage of this bill, Congress made no mention of the link between high-fat dairy products and heart disease or obesity. Given the over-saturation of the American market with low-cost, high-calorie and high-nutrient foods, the imperative for Congress to spend millions (an estimated $\$ 848,347,339$ in 2002) (5) on the dairy industry in order to "ensure that the people of the United States receive adequate nourishment" must be questioned.

Corn subsidies may also adversely affect health. The federal government spends an estimated \$ro billion a year aiding U.S. corn producers. Inexpensive products like high fructose corn syrup are now found in consumer goods from Coca-Cola to cookies. Researchers are beginning to distinguish the effects of corn syrup from other added sugars and to correlate its ubiquity with expanding waistlines of consumers around the world: soft drinks produced in the United States, and heavily implicated in obesity, almost all use high fructose corn syrup as a sweetener. 
U.S. corn syrup production has major implications for the United States' trade partners. Corn syrup entered Mexico at such an alarming rate that the Mexican Congress voted in 2002 to tax soft drinks containing high fructose corn syrup in order to preserve Mexico's suffering sugar industry. Given the recent World Trade Organization's ruling in favor of Brazil, which determined that U.S. cotton subsidies amount to unfair trading practices, a country such as Mexico could bring a similar complaint against U.S. policy regarding corn, or other agricultural subsidies.

FEDERAL PROGRAMS:

NATIONAL SCHOOL LUNCH PROGRAM

The National School Lunch Program (NSLP) is one of many programs instituted and controlled by the federal government. It provides a domestic outlet for the surplus output generated by the government's agriculture policies (6). Congress enacted the NSLP in the I940s to bolster U.S. agriculture by providing a ready-made market for surplus products, while improving nutrition for low income students. The U.S. Department of Agriculture (USDA) administers the NSLP, but Congress maintains and grants ultimate regulatory authority over the program. The program's scope has ebbed and flowed over the decades. The program's emphasis today shows concern for children's health, yet meals routinely include government-surplus meat and dairy products.

Under the federal Constitution, states have responsibility for education. Recently, state legislatures have taken on the health and welfare of their public school students by drafting a plethora of legislation related to the foods and beverages available in their schools. Many states have proposed legislation to regulate the foods available from the National School Lunch Program as well as outside vendors. This implicit shift from Federal to State control of the school lunch program has been especially apparent in the past year. Bills prescribing more state authority over the nutrition content of school foods are currently being considered in twenty states across the nation, including California, New York, Hawaii, Colorado, Oklahoma, Tennessee, and Vermont (7). These bills range in scope and mission from establishing nutritional standards for foods sold in schools, to requiring the nutritional content of food products to be displayed in school lunchrooms, to restricting the sale of foods and drinks with minimal or no nutritional value. This legislative activity represents a conscious 
effort on the part of state governments to increase control over the nutritional content of food and beverages served in schools. ${ }^{\mathrm{I}}$

FOOD HEALTH AND SAFETY: ADVERTISING

As described in accompanying articles, marketing of food to children contributes to the obesity epidemic. At present, the government in the United States does not restrict food advertising aimed at juveniles and adolescents. However, Congress does have the authority to prohibit advertising, if it is found to be deceptive or misleading. For example, in the case of cigarette and tobacco advertising, Congress espoused a public health rationale to prohibit ads on electronic media under the Federal Cigarette Labeling and Advertising Act (8). Congress could give a similar mandate to the Department of Commerce to limit the targeting of children by manufacturers of sugar cereals, caffeinated sodas, and fast foods, or it could codify such a directive to the Federal Communications Commission under the Children's Television Act (9).

A federal law prohibiting the advertising of junk food to children would have to survive a constitutional challenge (го). The Supreme Court has used the Central Hudson test to determine if the Constitution has been violated by regulation of "commercial speech": I) the speech has to be protected under the First Amendment; 2) in order to be protected, it must be lawful, and not misleading; 3) the prohibition or abridgement of protected speech must be intended to serve a substantial government interest; and 4) the legislation must actually serve the government interest, and be no more extensive than necessary (I I ).

Commercial speech is protected by the First Amendment; fast food and soft-drink commercials thus meet the first prong of Central Hudson. However, it is possible that such ads do not meet the requirements for constitutionally-protected speech. No courts have looked at the question of whether advertising junk food to children could be considered "misleading" if it confuses and unfairly manipulates children into influencing parents' purchases. Current research documents

\footnotetext{
I. Legislation proposed in Indiana that would require vending machines in public schools to carry more nutritional items faced fierce opposition from lobbyists for soft drink companies, an effort the bill's sponsor said places profits before student health. See Wrenn, D. Soft Drink Companies Fighting School Vending Machines Measure. The Courier Journal (Louisville, KY). 2004 February II. Also available from: http://www.courier-journal.com/localnews/2004/02/I rin/ met-3-vendo2 I I-45 I I.html [cited 2004 July I4]
} 
the link between advertising to children, the increasing consumption of fast foods and soft drinks, and obesity. Children are highly susceptible to messages and images in food commercials, and their diets have been found to mirror those messages (I2). While the abridgement of commercial speech is not generally acceptable in the U.S., the public is more willing to tolerate such regulation when the health of children is at stake.

Federal legislation aimed at regulating advertising faces an uphill battle, but advertising within schools offers a far more promising lever for change and legislative action on the state and local level. A U.S. General Accounting Office (GAO) report shows a drastic increase in commercial advertising in the public schools. The report found that:

... in-school marketing has become a growing industry. Some marketing professionals are increasingly targeting children in school, companies are becoming known for their success in negotiating contracts between school districts and beverage companies, and both educators and corporate managers are attending conferences to learn how to increase revenue from in-school marketing for their schools and companies (I3).

Although commercial activities in schools are covered by general federal and state laws applying to all businesses, the report identified nineteen states that currently have statutes or regulations that address school-related commercial activities. In fourteen of these states, statutes and regulations are not comprehensive and pertain only to some types of activities; in some states, laws prohibit or restrict activities; while in other states, laws authorize activities. For example, California laws restrict certain forms of advertising in schools, Michigan laws do not address commercial activities, and New Mexico laws allow advertisements in and on school buses (I4). As a result of this piecemeal regulation, in most states, local school boards usually assume the authority over policy decisions about advertisements within the schools or delegate these decisions to district officials.

Unencumbered by federal agricultural policy, lawmakers may influence the nutritional content of school meals, and are now doing so in a number of states. Others are considering legislation on vending machines in schools. Still other states are considering implementing taxes on snack foods and soft drinks. States considering the above options have recognized that obesity is not merely a matter of personal responsi- 
bility, but is a product of the whole food environment. As we move forward into the new century, the unique ability of states to act in the United States federal system may be constrained by the GATT/WTO frameworks governing international trade.

NEW LEGISLATIVE DEVELOPMENTS: LIMITING THE

JUDICIARY AND CONSTRAINING PUBLIC HEALTH

Recently introduced bills in Congress and state legislatures indicate two clear trends with regard to the obesity epidemic in the United States: I) the American public dislikes paternalistic legislation and prefers a solution to obesity that necessitates individual action, and 2) the American government has a vested interest in protecting the heavily-subsidized agriculture industry.

\section{Limiting the Judiciary}

Private enforcement of public health through the use of common law actions, e.g., torts, is a common part of U.S. jurisprudence. Private enforcement has been applied successfully to control dangerous medical devices, drugs, environmental contamination, auto safety, and, perhaps most famously, tobacco. New legislative initiatives seek to eliminate private enforcement as a public health strategy by restricting the jurisdiction of the courts. These efforts have two principal effects. First, they re-emphasize an ideology of personal responsibility by shifting the personal costs of obesity onto the consumer and foreclosing cost-sharing with industry through tort litigation. Second, the closure of the courts to obesity-related private actions increases reliance on traditional public health authorities.

The "Personal Responsibility in Food Consumption Act," or H.R. 339, also referred to mockingly as the "Cheeseburger Bill" (I 5 ) has been introduced in the House. The National Restaurant Association and other industry groups have also been very successful in persuading state legislators to introduce similar anti-lawsuit legislation. When enacted, these laws prohibit tort suits against fast food restaurants for having contributed to obesity and ill health of their customers. Similar legislation, introduced in the Senate, also seeks to protect restaurants, packaged food makers, distributors, advertisers and others from civil liability for an individual's weight gain or related health problems caused by the consumption of specific foods (I6). As of August 2004, H.R. 339 has passed the House of Representatives and 
awaits consideration in the Senate. The Senate bill, the Commonsense Consumption Act, remains in committee. A majority of the fifty states have now enacted or are considering one or the other type of legislation. Wisconsin's governor is notable for having vetoed such legislation ( $\mathrm{I} 7$ ).

\section{Constraining Public Health}

While constraining private enforcement, Congress has mandated action by the Public Health Service. Bills intended to address obesity are currently in House and Senate committees. In October 2003, the House passed a resolution "expressing the sense of the Congress with respect to obesity in the United States" ( I 8). In the short statement, Congress defined the role of the federal government in reversing the epidemic: to raise awareness of the health consequences of obesity, support basic, clinical and genetic research into the "causes of and improved treatment for obesity and overweightness [sic]," improve health care to better assess risk and treatment, and establish a "National Obesity Awareness Month" (I9). Many of the bills introduced in the current Congress reflect this individual rather than population approach.

The Improved Nutrition and Physical Activity (IMPACT) Act would amend the Public Health Service Act, providing grants for health professionals and local programs to promote healthy eating. The Obesity Prevention Act would amend the National School Lunch Act, to require increased physical activity, nutrition education, and consumption of fruits, vegetables, whole grains and low-fat dairy in schools. It would also establish a Commission on Obesity Treatment and Prevention. An interesting and telling caveat included in the text of the Act reads: "LIMITATION_Funds made available under this subsection shall not be used to disparage any agricultural commodity, food, or beverage" (20).

A focus on purely individual interventions to address overweight and obesity does not take into account the responsibility of government in promoting and maintaining the availability of high calorie foods in the marketplace, and for creating a protective atmosphere for both agribusiness and the fast food industries at the expense of the public's health. Of the agriculture-related bills recently introduced in Congress, only one suggests a rollback of government support of a subsidized crop-tobacco. In fact, one bill even proposed a reduction in the interest rate on loans to processors of sugar beets and sugar cane (2I), 
despite the fact that sugar has been singled out by the World Health Organization for its incontrovertible role in creating and maintaining the obesity epidemic.

PUBLIC HEALTH, CONGRESS, AND THE FUTURE OF OBESITY

\section{Present Legislative Choices}

On one basic level, Americans are obese because the United States government is more concerned with selling food products and artificially supporting the economy than with the effects of its economic policies on the public's health. Americans tout individualism as their most prized asset, and the paternalistic policies of public health successes in the early 2oth century are scorned today. Where Congress once claimed the imperative to protect the poor from dangerous products, ${ }^{2}$ today, it instead considers passage of laws that promote a rhetoric of personal responsibility and do little to change the unhealthy food environment.

Although thought unlikely to pass the Senate, the Personal Responsibility in Food Consumption Act (the "Cheeseburger Bill") would prohibit lawsuits against food companies for obesity-related injuries. By passing this bill, Congress would abrogate its responsibility for the epidemic. The food industry, from agriculture producers to fast food chains, has celebrated the bill's recent passage by the House. Public health organizations remain largely silent on the matter; the Center for Science in the Public Interest, Consumers Union, and the Physician's Committee for Responsible Medicine being notable exceptions. When the government continues promoting excess consumption of foods, injuring the population, perhaps we should not be surprised by the deliberate circumscription of individual legal remedies, accompanied by rhetoric of individual responsibility. How can we chart a course for public health?

\section{Future Legislative Choices}

Proposed changes in federal law should center on reforming the economic and built environments, and should refrain from overly pater-

2. Filled milk is an amalgam of skimmed milk and vegetable oil, and was sold as a milk substitute at the turn of the 2oth century. The product, still found on shelves today, was considered by Congress to be a threat to the public's health despite clear evidence that the product was not deleterious. 
nalistic restrictions on choice. Congress and state legislatures might act to protect the long-term health of the public rather than promote short-term economic gain; seek to reverse legislation that favors economic interests over health. Restricting advertising to children, mandating changes in nutrition guidelines, monitoring food production and distribution, and preserving the right of private enforcement are not radical suggestions.

Might public health advocates push Congress to leave outdated and irresponsible agriculture subsidies behind, in favor of a system that responsibly balances agricultural production needs with public health? Although a drastic end to subsidies might be disaster for some, there must be responsible global dialogue on agricultural policy, public health, and issues of food scarcity.

\section{CONCLUSION}

Public health, illustrated here with the example of obesity, is a problem for the world. As a leading producer of food and food products, and as a cultural force, U.S. policy helps set trends for all nations. Our Congress' action and inaction is scrutinized. If public health cannot engage Congress in a true discussion of how to fix inequities, the world's health will continue to suffer as the social and economic costs of obesity rise. The power of legislative action to exacerbate the problem of obesity has been demonstrated. What is necessary now is to harness legislative action as a legal lever to abate and control obesity both in the United States and globally. While legislative action can be one of the many causes of a food environment that facilitates obesity, it can most surely be a solution. There is a long legislative tradition in the United States of controlling and regulating food production, sales, and transport. What is required today is not the invention of a new kind of law, but a collective will to enact legislation for the public health in keeping with a long history of public health legislation.

Acknowledgments: The authors are grateful for the invaluable assistance of Ellen J. Fried and Nathaniel Towery. 


\section{REFERENCES}

I. Food, Drug and Cosmetic Act of I938, 2 I U.S.C. Sect. 3 I et seq. (2004).

2. The Child Nutrition Act of I966, creating the federal Women, Infants and Children (WIC) program, is another federally-mandated program capable of promoting good nutrition. See, Child Nutrition Act of I966, 42 U.S.C.A. Sect. I77I et seq. (2004).

3. Nestle, M. Food Politics: How the Food Industry Influences Nutrition and Health. Berkeley: University of California Press; 2002.

4. Congressional Findings and Declaration of Policy, 7 U.S.C.A. Sect. $450 \mathrm{I}$ (2002).

5. Environmental Working Group [homepage on the Internet]. Washington, DC: EWG; 22004 [cited 2004 July I4]. EWG Farm Subsidy Database [several pages]. Available from: www.ewg.org/farm/region.php?fips= $00000 \& y r=2002$

6. School Lunch Programs: Pilot projects, 42 U.S.C.A. Sect. I769 (2004).

7. Obesity Policy Report [homepage on the Internet]. Washington, DC: OPR; C2004 [cited 2004 July I4]. State Legislation Tracker [several pages]. Available from: www.obesitypolicy.com

8. Unlawful advertisements on medium of electronic communication, I 5 U.S.C.A. Sect. I335 (1970).

9. Standards for Children's Television Programming, 47 U.S.C.A Sect. 303 a (1990).

ıo. Unlike many other countries, the United States Constitution, Amendment I provides a strong legal barrier to the restriction of speech.

I I. Central Hudson Gas \& Elec. Corp. v. Public Serv. Comm'n of NY, 447 U.S. 557,566 (1980).

I2. The Role of Media in Childhood Obesity [monograph on the Internet]. Menlo Park, CA: The Henry J. Kaiser Family Foundation, 2004 [cited 2004 July I 4]. Available from: http://www.kff.org/entmedia/7030.cfm

I3. United States General Accounting Office. Commercial Activities in Schools [monograph on the Internet]. Washington, DC: GAO; 2000 [cited 2004 July I4]. Available from: www.gao.gov/archive/2000/heoo I 56.pdf

I4. Ibid.

I 5. Personal Responsibility in Food Consumption Act, H.R. 339, ro8th Cong., 2nd Sess. (2004).

I6. Commonsense Consumption Act of 2003, S. I428, I08th Congress (2004).

I7. Obesity Policy Report [homepage on the Internet]. Washington, DC: OPR; C2004 [cited 2004 July I4]. State Legislation Tracker [several pages]. Available from: www.obesitypolicy.com 
I 8. Providing for consideration of the bill (H.R. 2676) to amend the Internal Revenue Code of 1986 to restructure and reform the Internal Revenue Service, H. Cong. Res. 303, I08th Cong., Ist Sess. (Oct. I6, 2003). I9. Ibid.

20. To encourage innovative school-based activities to help reduce and prevent obesity among children, H.R. 2227, I08th Cong., Ist Sess. (May 22, 2003).

2I. A resolution to direct the Secretary of the Senate to request the return of certain pages, S. Res. I27, I08th Cong., Ist Sess. (April 30, 2003).

\section{SUMMARY}

Legislative bodies in the United States have often passed laws to regulate food in its production, content, and sale. Additionally, legislatures have created economic policies that directly affect the food supply and determine both the type and quantity of food available. Legislatively-enacted federal programs, such as the National School Lunch Program, also provide opportunities to promote good nutrition. These traditional areas of legislation represent the most efficient means to affect the food environment legislatively. While exploring legislative solutions to obesity, it is also imperative to monitor attempts by the legislature to constrain other public health strategies by limiting private enforcement and limiting the regulatory freedom of traditional public health authorities. 